\title{
Rigsfællesskab saml dig!
}

Af Sofie Rose og Simon Mølholm Olesen

Amerikanske, canadiske, kinesiske og russiske interesser i Arktis bliver stadigt mere tungtvejende, efterhånden som klimaforandringerne gradvist tvinger isen vak fra farvande, der hidtil ikke har kunnet besejles af handelsog krigsskibe. Dertil åbner klimaforandringerne mulighed for, at der kan udvindes diverse ressourcer. Staterne har meget at vinde ved at deltage $i$ kapløbet om Arktis. Stormagterne har ikke de store problemer med at få adgang til Arktis, men for mindre lande er det kun muligt, hvis de har et brohoved til Arktis. Og det er ikke sikkert, at Danmark, institutionaliseret i Rigsfællesskabet, bliver ved med at have det, når kalenderbladet runder 2050.

I 1979 fik Grønland tildelt hjemmestyre. I 2009 fik Grønland tildelt selvstyre. Og endelig formåede Aleqa Hammond at vinde Inatsisartut-valget i 2013 på en særdeles selvstændighedssøgende politik. Et af hendes berømte udsagn er, at hun gerne ser et helt selvstændigt Grønland, inden hun dør.
Bag disse fænomener gemmer sig et folkeligt ønske om grønlandsk selvstændighed, der er blevet så stærkt inden for de seneste årtier, at ethvert overlevelsesorienteret grønlandsk parti har tilpasset hele eller dele af sin politik i den retning (jf. figur 1). Således foreslog Inuit Ataqatigiit (IA), der ellers har hældet til at være orienteret mod rigsfællesskabet, i januar 2016 at nedtrappe bloktilskuddet med 10 mio. kr. årligt for at gøre Grønland mere selvbærende og mindre afhængig af Danmark. Figuren illustrerer spændingen i det politiske system i Grønland når det kommer til spørgsmålet om 'selvstændighed' over for 'tilknytning'. Flere partier kritiserer den nuværende indretning. Dette forhold kan vise sig sprængfarligt på flere indenrigs- og udenrigspolitiske fronter.

Alene ønsket om selvstændighed, også selvom det i bedste fald er illusorisk, kan siges at være en trojansk hest for Danmarks arktiske bestræbelser. Stormagterne vil være lidet tilskyndet til $\mathrm{fx}$ at imødekomme Danmarks nyligt indleverede territorialkrav i Arktis (2014), hvis der

Sofie Rose er stud.soc. i International Sikkerhed og Folkeret ved Syddansk Universitet.

Simon Mølholm Olesen er stud.mag. i Kulturhistorie ved Aarhus Universitet. Artiklen vandt førsteprisen i Det Udenrigspolitiske Selskabs og Udenrigsministeriets artikelkonkurrence. 


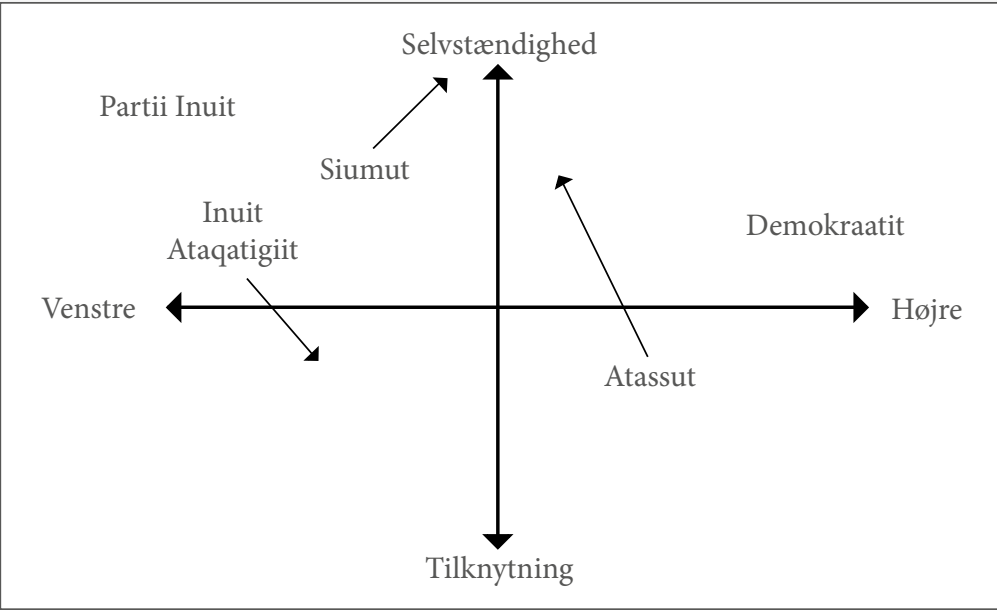

Fig. 1:

Det grønlandske partisystem med nylige holdningsskift [frit efter Pram Gad: 2014] er den mindste risiko for, at den konstellation, som giver Danmark adkomst til kravet - altså Rigsfællesskabet - risikerer at bryde sammen.

I artiklen skitseres den geopolitiske fare der opstår, hvis Grønland tilstås selvstændighed. Herefter kortlægges flere dybe og nære årsager til selvstændighedsønsket. Og endelig samles trådene til sidst i et bud på, hvordan og hvorfor Danmark først og fremmest skal rette alle sine bestræbelser mod at styrke Rigsfællesskabet, så udfordringer af global karakter, herunder miljøbeskyttelse, fortsat kan løses med solide danske aftryk.

\section{Selvstændighed er usikkerhed}

Ingen må være interesseret $\mathrm{i}$ åbenlyst at rykke meget ved den magtbalance, der har givet drømmere anledning til at erklære, at et isfrit Arktis vil facilitere internationalt samarbejde mellem stater, der $\mathrm{i}$ andre sammenhænge ellers ikke er de bedste venner.

Et selvstændigt Grønland vil muligvis indfri forståelige nationale drømme, håb og visioner i den grønlandske befolkning. Men det vil have en omkostning: den nordatlantiske sikkerhedssituation vil blive anspændt. Hvorfor? Jo, hvem siger, at det er en naturlov, at et selvstændigt Grønland kan eller vil høre under det vestlige alliancesystem? Grønland vil højst sandsynligt ikke bryde med Vesten hvis selvstændighed bliver en realitet. Men alene risikoen for en løs kanon på gletsjeren kan ikke være i nogens interesse.

En svag stat vil ikke blive tolereret i Arktis. På den ene side mener USA, at Monroe-doktrinen omfatter Grønland. Monroe-doktrinen siger, at USA ikke vil tillade ikke-amerikanske magter, herunder Rusland, at trænge ind på det amerikanske kontinent. Dette har været ræsonnementet bag den amerikanske tilstedeværelse i Grønland siden Kauffmann-aftalen af 9. april 1941.

Et selvstændigt Grønland vil på baggrund af Monroe-doktrinen tvinge USA til at træffe forholdsregler, der endegyldigt vil knuse drømmen om selvstændighed. 
Og på den anden side mener Rusland gennem den logik, der er blevet døbt Putin-doktrinen, at store dele af Arktis hører under den russiske indflydelsessfære. Således har Rusland indgivet krav på områder i Arktis, der stedvist overlapper de danske krav, plantet det russiske flag på den arktiske havbund og tilpasset sine militære kapabiliteter de arktiske forhold.

Nævnte forsvarspolitikker udgør en global trussel, idet de har potentiale til at udløse oparbejdet spænding i det fænomen, der er blevet kaldt 'sikkerhedsdilemmaet'. Den nationale sikkerhed er det vigtigste om end ikke det eneste mål for staten. Hvis sikkerheden trues, så vil konflikten blusse op, fordi der opstår mistillid mellem staterne om hinandens motiver. Mistillid er uomgængeligt en af de største trusler mod verdensfreden. Alle krige grunder i mistillid mellem to eller flere stater.

Samtidig forsøger nye spillere såsom Kina, jævnfør kinesiske ekspeditioner til Arktis og ønsker om optagelse i Arktisk Råd, at få adgang til Arktis. Ingredienserne til en slagkraftig konfrontation er helt klart tilstede. Også selvom udsigten til konflikt virker iskold i øjeblikket.

\section{Stormagtslogik}

Visse skeptikere vil givetvis indvende, at en militær konfrontation ikke kan finde sted i Arktis, fordi de internationale institutioner vil forhindre det. Dertil er oven nævnte stormagter alle i besiddelse af MAD-våben (Mutual Assured Destruction), og det har i sig selv en afskrækkende virkning. Problemet er, at argumenterne ikke holder i et spil, der følger stormagternes logik.

På den ene side vil FN's Sikkerhedsråd aldrig kunne pålægge stormagterne Kina, Rusland og USA, der deltager eller ønsker at deltage i Arktis, sanktioner, fordi de alle besidder $\mathrm{FN}$-vetoret. Organisationens eneste våben er fordømmelsen. Fordømmelsens magt kan måske få små og mellemstore lande til at bøje af, men stormagterne vil højest svaje let, når valget står mellem verdenspolitisk anseelse og statslige interesser.

Talrige eksempler viser stormagternes udprægede ligegyldighed over for retorikkens bløde magt. FN kan muligvis facilitere uformelle samtaler på statslederniveau til generalforsamlingerne. Det kan være givtigt. Men FN har aldrig haft evne eller vilje til at diktere stormagternes adfærd, fordi det netop er stormagterne, der leder FN. Regler er trods alt nemmest at følge, når der ikke er behov for dem. Sagt på anden vis: Internationalt samarbejde er en smuk og værdifuld tanke, men verden er endnu ikke indrettet efter et kantiansk verdensbillede af fred og fordragelighed.

Og det billede holder, fordi stormagterne ikke kan eller vil erkende, at fred både er mål (tillid) og middel (kontinuitet) til at sikre fred.

På den anden side vil MAD-våben ikke nødvendigvis afskrække stater fra hverken stedfortræderkrig eller krig. Visse teoretikere mener, at Sovjetunionens og USA's besiddelse af MAD-våben under den kolde krig var med til at forhindre, at konflikten blev varm. MAD-våben skulle endda have haft en stabiliserende effekt i det anspændte forhold mellem Vest og Øst.

Koreakrigen og Vietnamkrigen samt den afghansk-sovjetiske krig kan i den logik tolkes som ventiler for konfliktpotentialet. Disse krige var med andre ord stedfortræderkrige mellem stormagterne. Ukraine-krisen er alene ved bru- 
gen af ordet 'krise' et udmærket eksempel på en nutidig stedfortræderkrig mellem Vesten og Rusland. Vesten har udsendt rådgivere, mens Rusland har sendt 'små grønne mænd' eller soldater uden kendemærker til Ukraine. Begge parter råder over $\mathrm{MAD}$-våben, men har heldigvis ikke taget dem i brug.

1999-krigen mellem Indien og Pakistan havde rod i komplekse og stærke religiøsnationale følelser. Selvom krigen antog konventionel karakter, altså soldater kom i kamp med hinanden, så blev der ikke anvendt $\mathrm{MAD}$-våben, endskønt begge parter rådede over sådanne i deres arsenaler.

Sammenløbet af disse logikker har fået iagttagere til at drømme sig hen til en verden, hvor krigens logik ikke synes at kunne eksistere under koldere himmelstrøg. At den øvrige verden står i brand, herunder i Syrien og Ukraine, anført af de sædvanlige stater, synes ikke at tilskynde til revurdering af Arktis som et konflikternes helle.

Men man skal ikke tage fejl. Mennesket havde ikke forestillet sig krigsførelse i luften og under vandet, før den teknologiske udvikling frembragte flyvemaskiner og ubåde. I dag er krig utænkeligt uden begge. Når isen tvinges fra Arktis af klimaforandringerne, desuagtet COP21's ambitiøse planer, så åbnes en ny arena for konflikt. Hvis der ydermere kan udvindes værdifulde naturressourcer, så vil spændingerne kun øges endnu mere.

Derfor må det smerteligt sandes, at der ikke findes noget helle, især ikke når dette forestillede helle omfatter en hel verdensdel, der kan se sig fri for krigstrommens forførende toner. Hvis der tilmed opstår en svagelig arktisk stat i dette forestillede helle, der strækker sig over et område på størrelse med Vesteuropa beboet af 55.000 mennesker, så skal der ikke mange forkerte antydninger til, førend denne lille stat opsluges af store kræfter. Og som verden har set i forbindelse med Ukraine-'krisen', så er nationalt territorium endnu ikke helligt.

Heldigvis kan der træffes nogle valg, der mindsker konfliktpotentialet - og dermed styrker mulighederne for fred $\mathrm{i}$ Arktis.

\section{Fredsskabende bufferzone}

Danmark har gennem sit rigsfællesskab med Grønland en rigtig god mulighed for at virke som en fredsmæglende buffer mellem stormagterne. Bufferzoner har i fortid og nutid ansporet til at styrke det internationale samarbejde, fordi parterne ikke har følt sig truet af den nuværende konstellation. Dette kan måske forklare, hvorfor nogle drømmende betragter det arktiske område som et helle? Hvis bufferzonen eller status quo forsvinder, så opstår en helt anderledes geostrategisk virkelighed, som stormagterne skal forholde sig aktivt til.

Ophør af status quo oplevede kongeriget under Anden Verdenskrig, hvor Island blev besat af de allierede, og derefter erklærede sig selvstændigt fra Danmark (1944). Besættelsen af Island skete for at komme tyskerne i forkøbet, fordi Island udgør en formidabel geostrategisk trædesten mellem Nordamerika og Europa. På daværende tidspunkt var Storbritannien, Sovjetunionen og USA som bekendt allierede imod Tyskland. Tysklands besættelse af Danmark satte bufferzonen ud af kraft, og det blev udnyttet af Storbritannien og USA, da de besatte Island. 
Besættelsen medførte to ting. På den ene side blev Island føjet til det vestlige alliancesystem som geostrategisk trædesten mellem Nordamerika og Europa. Det skulle blive nyttigt under den kolde krig. Og på den anden side fritog den nære tilknytning til det vestlige alliancesystem, især USA, Island for at oprette sit eget militær. Island var effektivt undergivet USA i den kolde krig.

I dag er den amerikanske tilstedeværelse i Island droslet ned, og det skyldes givetvis, at stormagternes fokus er blevet rettet længere mod nord. Island indgår som anerkendt medlem i fx NATO-alliancen; Island er sikret.

Den dansk-grønlandske bufferzone kan befinde sig i et potentielt dilemma, der vil minde om det, islændingene stod overfor $\mathrm{i}$ 1940'erne. Hvis en geostrategisk bufferzone opløses enten frivilligt eller ufrivilligt, så vil stormagterne under hensyntagen til omtalte stormagtslogik forsøge at udligne det nyopståede tryk. Islands besættelse foregik under Anden Verdenskrig, hvor alliancepartnerne, der efterfølgende skulle blive uvenner, givetvis accepterede udfyldningen af den nordatlantiske bufferzone af hensyn til krigsindsatsen.

Såfremt Grønland udtræder af rigsfællesskabet i fredstid, hvilket synes mest sandsynligt, så kan det medføre, at fredstid afløses af krigstid, fordi en fredelig udfyldning af kongerigets hidtidige (og anerkendte) bufferzone synes mindre selvfølgelig end i det islandske tilfælde. Dette hænger sammen med, at konflikten antageligt vil stå mellem stater, der under Anden Verdenskrig var enige om at løse det islandske spørgsmål for at slå en fælles fjende.

I et hele kan det medføre, at aftaler, samarbejde og statslig (grønlandsk) suveræ- nitet underkendes til fordel for logikken i stormagtsspillet. Verdenssamfundet har traditionelt set mod Danmark, når fornyelse og samarbejde mellem staterne skulle søsættes eller sikres. Danmark har historisk haft en særdeles stolt tradition som brobygger mellem blokkene i verdenssamfundet, og det kan i vid udstrækning antageligt tilskrives forbindelsen til de nordligste breddegrader. Danmark skal erkende og udnytte det potentiale til at forebygge konflikter i Arktis. Af natur er international politik som tidligere nævnt indrettet ligeligt på fred og krig, men der skal, jævnfør sikkerhedsdilemmaet, ikke meget til, før fredens lykke afløses af krigens gru.

Regler er jo trods alt nemmest at følge, når der ikke er behov for dem. Dermed må styrkelsen af det dansk-grønlandske forhold i rigsfællesskabet være nøglepunktet for Danmarks udenrigspolitiske bestræbelser i Arktis. Dette er lettere sagt end gjort. Artiklen har allerede berørt det faktum, at grønlandske selvstændighedstanker har stor opbakning i den grønlandske befolkning, og det gør en styrkelse af rigsfællesskabet, og dermed udførelsen af Danmarks arktiske politik, besværlig. Dog ikke helt umulig. Specielt ikke, hvis Danmark har øje for de historiske udviklinger, der skabte grobund for følelserne.

\section{Afkoloniseringen som referenceramme}

Fra slutningen af 1940'erne stod det efterhånden klart, at kolonitiden var ovre. Nye FN-medlemmer begyndte, anført af en uhellig alliance i form af Sovjetunionen og USA, at presse kolonirigerne til at afvikle kolonierne eller tildele kolonierne mere selvstyre. I det spændingsfelt befandt Danmark sig. 
Grundlovsændringen af 1953 blev et stort højdepunkt i de danske bestræbelser. Med ét pennestrøg var Grønland inkorporeret i Danmark, grundloven gælder nemlig for "alle dele af Danmarks Rige", hvilket blev anerkendt under FN-generalforsamlingen i 1954 uden kritik. Danmark kom rettidigt ud af kolonimagternes selskab, for allerede 15 år senere var de fleste kolonier gledet de tilbageværende kolonimagter af hænde.

\section{1946 modtog Udenrigsministeriet en} rundskrivelse fra FN om, hvorvidt Danmark havde nogen kolonier. Alle FNmedlemmer modtog rundskrivelsen, og så var det op til de nationale regeringer at udfærdige et svar til FN. Ministeriets embedsmænd vægrede sig. Det var efter deres mening forkert at betragte Grønland som en koloni i traditionel forstand; ingen var hverken blevet udbyttet eller dræbt under den danske administration. Så vidt ministeriet da vidste. Hvad udtrykte den danske tilstedeværelse i Grønland så? Ingen kunne rigtig give et svar. Ministeriet valgte derfor, påvirket af den indflydelsesrige landstingsmand Hermod Lannung (RV), at føje Grønland til kolonilisten.

Beslutningen satte Danmark i en kilden situation. På den ene side kom Danmark i selskab med mere autoritære kolonimagter såsom Belgien og Frankrig, og på den anden side fik Danmark lejlighed til at udforme FN's kolonipolitik i en retning, der gavnede danske interesser. Samtidig betød de indledende manøvrer til den kolde krig, at Danmark gennem besiddelsen af Grønland kom til at fylde mere på den internationale scene end ellers. Samtidens danske diplomater døbte fænomenet 'Grønlandskortet', der kunne smides som trumf $\mathrm{i}$ internationale forhandlinger. Det gav indflydelse, og den ville Danmark for næsten alt i verden ikke miste.

Danmark mistede ikke indflydelse. Takket være meget dygtigt diplomati lykkedes det at føje et centralt punkt til den faktorliste, der afgjorde, hvorvidt FN kunne betragte den givne koloni som afviklet eller ej. Punktet var, hvis kolonimagten inkorporerede kolonien som ligeværdig del i moderlandet, så ville den efterhånden ubehagelige betegnelse 'koloni' bortfalde.

For at kunne overbevise FN om, at Grønland vitterlig var blevet en ligeværdig og integreret del af Danmark, indledtes Nyordningen af 1950, der med en særdeles gennemgribende kraftanstrengelse $ø$ skede at modernisere det grønlandske samfund. Grønland skulle være så dansk, at FN ikke kunne rette et eneste kritikpunkt mod Danmark. Diplomaterne var fokuseret på at befri Danmark for ubehaget ved at skulle stå skoleret i FN samtidig med, at de dydigt forsøgte at bevare opfattelsen af Danmark som hidhørende de liberale kolonimagter, hvilket blev brugt til at oparbejde mere indflydelse som brobygger mellem blokdannelserne.

Grundlovsændringen af 1953 blev et stort højdepunkt i de danske bestræbelser. Med ét pennestrøg var Grønland inkorporeret i Danmark, grundloven gælder nemlig for "alle dele af Danmarks Rige", hvilket blev anerkendt under FNgeneralforsamlingen i 1954 uden kritik. Danmark kom rettidigt ud af kolonimagternes selskab, for allerede 15 år senere var de fleste kolonier gledet de tilbageværende kolonimagter af hænde.

Fortsat dansk indflydelse i Arktis havde den pris, at det dansk-grønlandske for- 
hold i de følgende årtier blev dramatisk forværret. I 1952-53 forekom tre hændelser, der har spøgt i kulissen siden.

Det grønlandske landsråd fik besked på at godkende den amtslige integration $\mathrm{i}$ Danmark uden synderlig behandlingstid. Landsrådets samtykke skulle bruges til at understøtte de danske argumenter i FN; grønlænderne ønskede på papiret selv integrationen. 22 grønlandske børn blev tvunget til Danmark for at lære ordentligt dansk. De skulle bruges til at vise, at Danmark og Grønland var ét samlet land. Og endelig blev Thule-folket tvangsflyttet, så USA kunne bygge en vigtig militærbase rettet imod Sovjetunionen.

Flytningen gav yderst vigtig goodwill i Washington, og den er siden blevet brugt flittigt til at støtte Danmarks udenrigspolitiske bestræbelser i flere sammenhænge. Arbejdet med at sikre international indflydelse medførte også, at danskerne tidligt skabte præcedens for at overhøre den grønlandske befolkning. Tendensen til at overhøre grønlænderne i politiske spørgsmål bidrog givetvis til at øge den fremmedgørelse, der i dag kendetegner det dansk-grønlandske forhold; en fremmedgørelse som betyder, at grønlænderne for alt i verden vil blive Danmark kvit (jf. IA-partiets forslag om gradvist at nedtrappe bloktilskuddet), så Grønland kan stå på egne ben.

Afkoloniseringen er på mange måder det mørkeste kapitel i den dansk-grønlandske historie, fordi det skabte (velbegrundet) splittelse mellem Danmark og Grønland.

\section{Historiens kølige dom?}

Vi har overordnet skitseret, hvorledes stormagterne af historiske grunde betragter rigsfællesskabet som en brobyg- gende og fredsskabende bufferzone, og hvorfor Danmarks forbindelse til Grønland har leveret afgørende goodwill til flere af kongerigets udenrigspolitiske bestræbelser.

Bufferzonen har sandsynligvis medvirket til, at stormagtslogikken om krigens nødvendighed når staten trues af andre stater, er blevet mindsket i Arktis. Flere iagttagere har på den baggrund således fejlagtigt udråbt Arktis til et helle, hvor krigens gru ikke kan indfinde sig.

Faren heri er tosidet, og den betinger, at alle kræfter rettes mod indvortes konsolidering til gavn for udvortes bestræbelser. På den ene side bør viden om afkoloniseringen give danske beslutningstagere redskaber til at forstå og imødekomme de meget stærke følelser i den grønlandske befolkning, der er blevet ignoreret til stor skade for Rigsfællesskabet. Det virker omsonst at tro, at Danmark fortsat kan handle ligesom kongehovedet på den hobbeske leviathan, der begrunder sin enevoldsmagt med, at kroppen, fx Grønland, ikke kan fungere uden kongehovedets vejledning. Kolonitiden sluttede i løbet af 1960'erne, muligvis 1970'erne, og dette skal Danmark tage hensyn til, hvis rigsfællesskabet skal undgå at sprække, knække og hensygne. Et splittet rigsfællesskab står udenrigspolitisk svagt, når der fx skal forhandles om territorialkrav i Arktis eller udarbejdes international miljøpolitik med et grønt dansk aftryk.

Og på den anden side har rigsfællesskabet en forpligtelse til at arbejde for fred i et internationalt system, der formentligt ikke i den nærmeste fremtid indrettes efter kantiansk fred. Rigsfællesskabet kan bidrage til at gøre verden mere sikker og grøn, og det vil tillige 
give Danmark handelspolitiske fordele som følge af bl.a. vores førerposition på grøn udvikling. Men det kræver snarrådighed og vilje.

Alternativet er, at vi kommer til at høre historiens kølige dom 'FOR SENT!', hvis ikke vi træffer dispositioner, der kan imødekomme de kræfter, der indenrigsog udenrigspolitisk truer vores arktiske bestræbelser. For sent til at sikre en stabil fred, for sent til at beskytte miljøet, når ishavet bliver mere isfrit, for sent til at kunne opfylde rigsfællesskabets arktiske udenrigspolitik i sin helhed.

\section{Gensidighed}

Et velkendt ordsprog sagde om de østrigske habsburgere, at de blot skulle lade andre kriges, imens de selv giftede sig. Habsburgerne skulle med andre ord indgå alliancer, der sikrede land og rigdom uden krigens omkostninger til følge. Nogenlunde samme logik kan bruges til at anskue, hvorledes Danmarks geostrategiske position kan sikres og udvides i Arktis samtidig med, at Grønland forskånes for at befinde sig i midten af den potentielle krigsskueplads.

I modsætning til Habsburg så skal Danmark ikke udvide sit i forvejen store og stærke alliancenetværk. Det behøves overhovedet ikke. Tværtimod. Danmark bør dyrke og styrke sit 300-årige ægteskab med Grønland, hvis det danske brohoved til Arktis fortsat skal være åbent. Krig vil uundgåeligt opstå i forskellige dele af verden, når store og små interesser støder sammen. Historien rummer talrige eksempler.

Det må i særdeleshed være Udenrigsministeriets, ja i almindelighed alle rettænkende beslutningstageres fornemmeste opgave at holde rigsfællesskabet fri af konflikterne ved at sikre den danskgrønlandske bufferzones fortsatte beståen. Statens interesser såsom fiskeri, miljøbeskyttelse og naturressourcer vil på kort og længere sigt derigennem styrkes. Derfor er en gensidig forbindelse og respekt mellem Danmark og Grønland helt afgørende.

Gensidighed skal være det adelsmærke, der bør kendetegne fremtidens bestræbelser på at hævde kongerigets interesser, forankret i ønsket om at skabe varig fred. Rigsfællesskabet skal sindrigt udnytte den bufferzone, herunder 'Grønlandskortet', som det besidder, til at få disse politikker gennemført. Essentielt set arbejder disse udenrigspolitiske betragtninger og forslag på flere planer. Det må og skal erkendes.

Vi tror på et fredeligt Arktis; men vi tror ikke på, at Arktis har været, er eller kan blive et konflikternes helle. Arktis kan højest holdes fredeligt af en bufferzone ligesom den dansk-grønlandske; det må ikke glemmes (jf. udfyldningen af den dansk-islandske bufferzone under Anden Verdenskrig). Vi skal udnytte det. Derfor bør konsolidering af det rigsfællesskabelige samarbejde være førsteprioritet for vores bestræbelser i Arktis. Ellers kan alle vores øvrige og vigtige bestræbelser være fuldstændig ligegyldige. Helt og aldeles ligegyldige.

Danmark og Grønland skal om nødvendigt se en 'parterapeut', hvis ægteskabet ikke skal briste. Parterapeuten kan tage form som en fælles forsoningskommission, institutionaliseret inddragelse af grønlændere ved grønlandsrelevante forhandlinger til finansloven, stærkere værn om og integration af grønlændere i Danmark, udjævning af begge parters skadelige fordomme som 
forestillingerne om den alkoholiserede grønlænder og sexhungrende dansker, støtte til enkelte rigsdele i sager om disses interesser (jf. Færøerne vs. EU) samt undskyldninger, hvor de kan facilitere øget samarbejde.

Visse sandheder risikerer at bringes ud af skammens mørke. Skam er en lille pris at betale, hvis det kan standse blødningen fra det åbne sår, der er årsag til skammen. Såret skal lukkes. Italesættelse af fortiden til gavn for nutiden bør være et fælles pejle- mærke. Følelsen af skam må samtidig ikke sætte nogen af parterne i en selvhævdelsens position, hvor fordomme, grådighed og/eller hævngerrighed driver den ene til at kræve f.eks. pengebod af den anden. For så er vi atter på vej mod opløsning. Og så kan Danmark lige så godt opgive Arktis, eftersom forudsætningen for den danske tilstedeværelse er betinget af rigsfællesskabets fortsatte beståen. 
